\title{
全米聾情報センター（NICD）における情報サービス
}

\author{
齋 藤 友介 ${ }^{1}$ 中 嶋和 $夫^{2}$ 高山忠 雄 $^{3}$ \\ 筑波大学大学院心身障害学研究科, ${ }^{2}$ 北海道医療大学看護福祉学部, ${ }^{3}$ 岡山県立大学保健福祉学部
}

Saito Y. (Institute Special Education, University of Tsukuba. 1-1-1, Tennodai, Tsukuba 305, Japan) : Information Services at the National Information Center on Deafness (NICD).Igaku Toshokan $1995 ; 42(1)$ : 73-79.

This article reports on the services provided by the National Information Center on Deafness, or NICD, at Gallaudet University. Supported by a number of facilities for the hearing impaired in the United States, NICD was founded in 1980 as a nonprofit specialized information center. NICD's information services consist of the collection, development, and provision of information on deafness. The information collected ranges over such topics as education, society, culture and so on. There are about 750 files of information at NICD and they are classified into several topics. By quickly responding to clients' requests, in fiscal year 1992, NICD answered $94 \%$ of 10400 references. To provide quick answering services, NICD has prepared over 100 original booklets on each topic. Clients have access to NICD in person, by telephone, facsimile. TDD, or E-mail. All 5 full-time staff members, including a systems engineer, can communicate with hearing impaired clients by American sign language (ASL). To make effective information services accessible throughout the country, NICD has close connections with various local facilities and 9 Gallaudet University regional centers. At present NICD is planning to establish a nationwide data base system using an on-line computer network.

\section{I .はじめに}

情報へのアクセスに困難を伴う聴覚障害者の社 会参加実現ならびに生活の質（QOL）を向上さ せるうえで情報支援の果たす役割は大きい。わが 国においては学齢聴覚障害児ならびに養育者に対 しては竩学校や病院が中心となって教育やリハビ リテーションに関する情報を提供している。しか しながら，成人聴覚障害者に対する情報支援は視 覚障害者などと比較してみても遅帯しており，今 後, 聴覚障害者のサービス・ニードに即した情報

\footnotetext{
'Yusuke SAITO : テ305 つくば市天王台 1-1-1.

${ }^{2}$ Kazuo NAKAJIMA, ${ }^{3}$ Tadao TAKAYAMA.
}

(1994 年 12 月 27 日 受理)
支援システムの確立が急がれるところである。

近年, わが国では身体障害者福祉法の一部改正 に伴い, 従来の点字図書館の条項が視聴覚障害者 情報提供施設に改められたことから, 今後, 聴覚 障害者情報提供施設（以下，情報提供施設）が都 道府県ならびに政令指定都市を中心に各地に漸次 設置されていくことが予想される。しかしながら, 情報提供施設が提供すべきサービス内容等につい ては関係者間であ十分な共通認識が形成されてお らず，聴覚障害者に対する情報支援モデルのあり 方が問われているところである ${ }^{4,7,8)} 。$

筆者らはこれまでわが国における聴覚障害者に 対する情報支援システムを開発するための予備調 査として，欧米諸外国における聴覚障害者情報サー ビス機関における情報サービスの現況について調 
査を進めてきた ${ }^{5.6)}$ このたび，その一環として米 国ギャローデット大学に設置されている, 全米竩 情報センター（National Information Center on Deafness : NICD) を訪問し, 同センターの 情報サービスについて調查した。本論文はその概 要を紹介することに目的がある。

\section{II . 全米襲情報センター設立の背景}

全米竩情報センターが置かれているギャローデッ ト大学は米国ワシントン DC にある, 教養系 4 学 部をもつ米国唯一の聴覚障害者のための大学であ る。ギャローデット大学の起源は 19 世紀中頃に まで遡り, 同大学の歴史は米国壟者の歩んできた 歴史といっても過言ではないであろう。なお, 1988年の学長選挙で選ばれた現学長キング・ジョー ダン氏は同大学の歴史上はじめての壟者の学長で あり, 彼の学長就任は近年米国で施行された「障 害を持つアメリカ人法 (American Disability Act : ADA)」の成立に大きな影響を与えたこと は全米の市民もよく知るところとなっている。米 国ではギャローデット大学のほかに, 聴覚口話法 による聴覚障害者の健聴者社会への適応を目指す 国立龍工科大学 (NTID) や, カリフォルニア州 立大学ノースリッジ校など, 聴覚障害者に対する 大学教育を積極的に行う大学がある。ギャローデッ

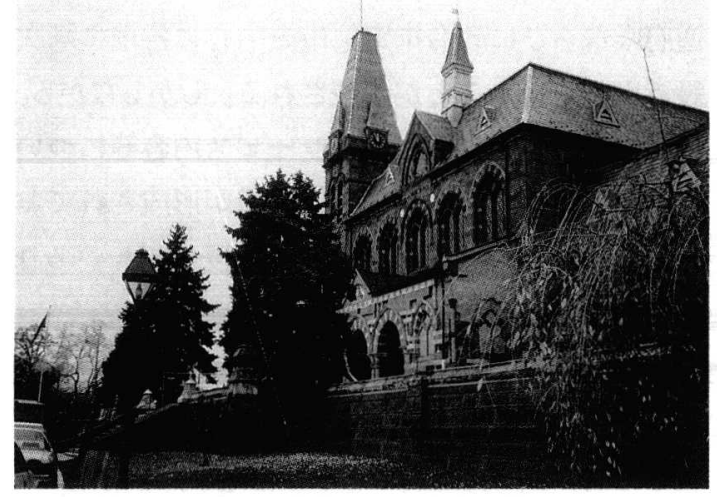

図 1. ギャローデット大学チャペル
ト大学はこれらの大学のなかでも, 手話に代表さ れる「deaf culture（襲文化）」を最も尊重する 校風を誇っており, 現在, 米国のみならず世界各 国から集まった約 2000 人の学生がアメスラン (American Sign Language) を共通言語にキャ ンパス生活を送っている ${ }^{2)}$ 。同大学では学部と大 学院の学生に対する教育と教員の研究活動のほか に, 生涯教育部, 9 箇所の地方センター, 研究所, 全米襲法律センター, 出版部, 国際部, 全米襲情 報センター（NICD）などの独立した専門部局が 整備されており, 大学の情報資源を大学内外に提 供している。

ところで, 聴覚障害に関する研究を行うギャロー デット大学に対しては, 従来より, 大学内外加 コミュニケーション方法, 教育機関, 補聴器, 福 祉サービスなど, 聴覚障害に関する様々な問い合 わせがあった。今回報告する全米壟情報センター （NICD）が設立されるまでは，これらの問い合 わせに対し，郵便事務員や電話オペレーターがそ のつど，同大学のスタッフのなかから質問内容に ふさわしい人間を選びだし, 回答を求めていた。 全米襲情報センター（NICD）はこれらの内外か らの問い合わせを効率的に一括処理する部局とし て 1980 年に設立された。現在は聴覚障害者を含 む5 名の常勤スタッフと6名のボランティアがサー ビスに従事している。なお，人件費をのぞく NICD の 1993 年度の運営予算は日本円に換算す ると約 500 万円とのことである。

\section{NICD の情報サービスの概要}

\section{1. サービス内容}

全米壟情報センター（NICD）には聴覚障害に 関する様々な問い合わせがあるが，NICD ではク ライエントの問い合わせに回答するために，1） 調査・情報収集，2）資料の編集・作成，3）情報 提供, を行っている。NICD がある Merrill Learn- 


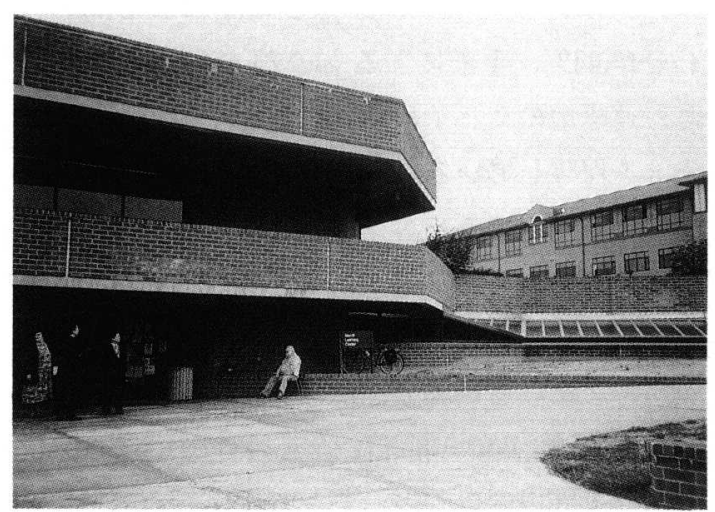

図 2.NICD がある Merrill Learning Center

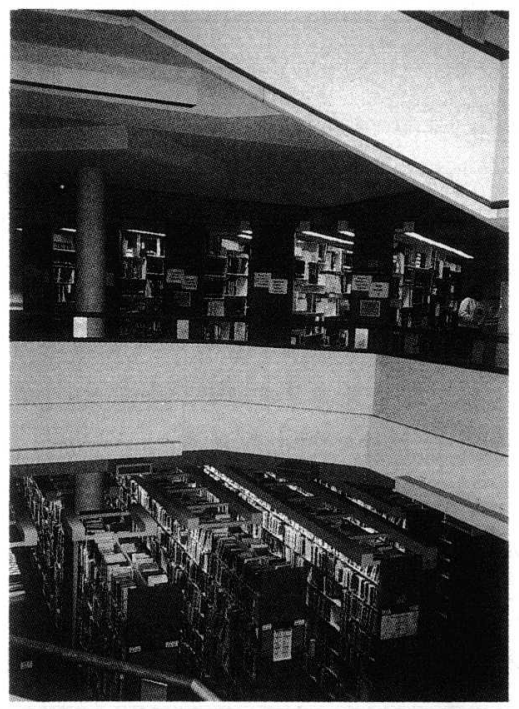

図3.ギャローデット大学図書館

ing Center (図 2 ) はキャンパス中央に位置し, ほかに図書館とテレビ放送スタジオが入っており, 聴覚障害メディアセンターをなしている。ギャロー デット大学図書館では聴覚障害に関連した世界最 大級のコレクションを所蔵しており, 歴史的に貴 重な文献む数多く保存されている。NICD スタッ フが調査・情報収集する際にも,この図書館が重 要な情報源となっている。NICD でクライエント から問い合わせが多い相談事項としては, 壟に関 する事項, コミュニケーションと手話に関する事 項, 襲教育に関する事項, ギャローデット大学に
表 1. NICD 利用者の内訳

\begin{tabular}{lc}
\hline 一般人 & $15 \%$ \\
学生 & $13 \%$ \\
聴覚障害者 & $12 \%$ \\
聴覚障害専門家 & $10 \%$ \\
一般教育機関 & $7 \%$ \\
手話通訳などの支援専門家 & $5 \%$ \\
ギャローデット大学職員 & $4 \%$ \\
聴覚障害児の養育者 & $4 \%$ \\
図書館関係者 & $3 \%$ \\
聴覚障害者の知人, 友人 & $3 \%$ \\
社会福祉関係者 & $3 \%$ \\
その他 & $21 \%$ \\
\hline
\end{tabular}

関する事項, 壟や聴覚障害者のための各種サービ スに関する事項（精神衛生, アルコール依存症治 療, Advocacy) などが挙げられる。クライエン トはNICD を様々な目的で利用しており, 一例と して, 聴覚障害をもつクライエントが, 自分が暮 らす地域における娛楽サークルを探すために問い 合わせてきたり, 聴覚障害を勉強する学生が論文 作成に必要な資料を探すためにやって来ることも あるという。

なお，クライエントへのサービス件数は NICD が開設当初の 1980 年が 1600 件, 近年では 1992 年が 10400 件, 1993 年が 11000 件となっており, 近年は 1 万件台を推移している。

クライエントの内訳としては一般人からの問い 合わせが 15\%, 学生が 13\%, 聴覚障害者が 12\%, 聴覚障害専門家が 10\%と多い。ほかに，一般教 育機関からの問い合わせが $7 \%$, 手話通訳などの 支援専門家が $5 \%$ ，ギャローデット大学職員が 4 $\%$, 聴覚障害児の養育者が $4 \%$, 図書館関係者が $3 \%$, 聴覚障害者の知人や友人が $3 \%$, 社会福祉 関係者からが $3 \%$ ，その他が $21 \%$ となっている （表 1 ）。著者らの予想に反して, 聴覚障害者以外 のクライエントの利用が多く, NICD が聴覚障害 


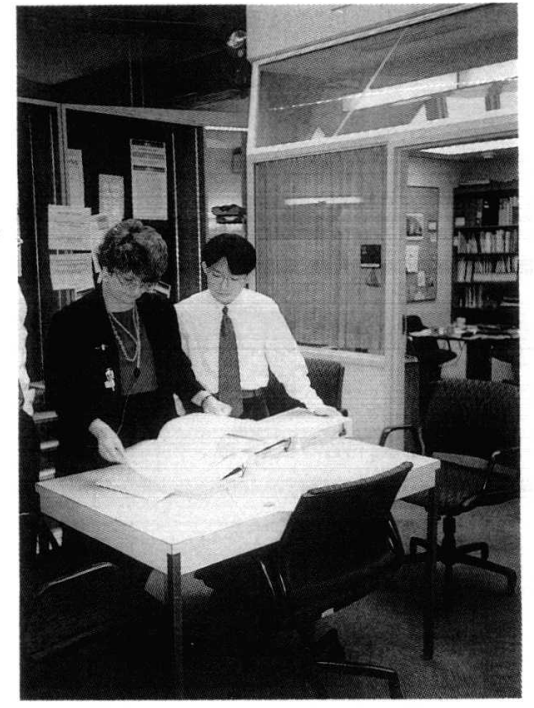

図 4 、ロレイン女史と著者

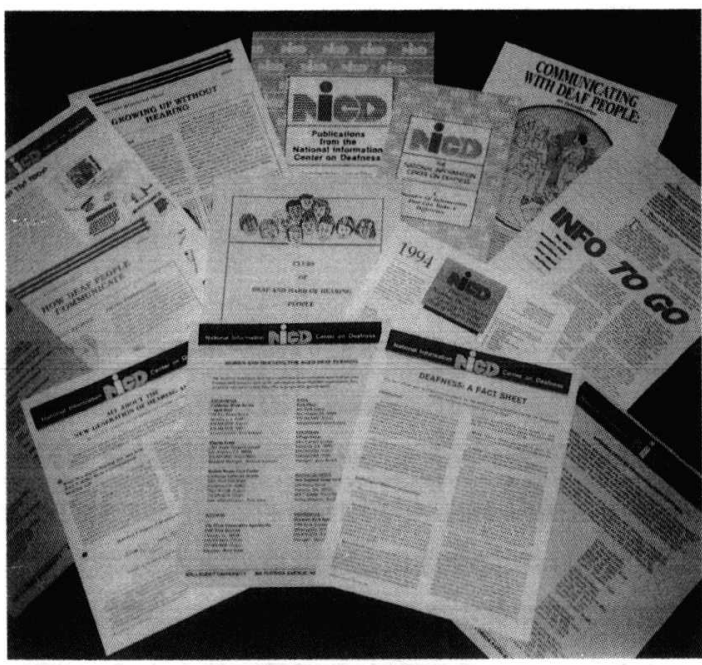

図 5.NICD が発行するリーフレット

者のみを対象とする閉ざされた機関ではなく，健 聴者からあ社会資源として認知されていることが わかる。なお，NICDではクライエントの制限を 一切設けておらず，大学外はむちろんのこと全米 各地からの問い合わせに対応している。NICDで はクライエントのアクセス方法として直接来所の ほかに，電話や手紙によるアクセスを保障してい る。直接来所が $9 \%$ と少ないのに対して, 電子メー
ル, TDD, ファックスを含む電話による問い合 わせが $44 \%$ ，手紙によるものが $47 \%$ となってお り, 遠隔地のクライエントに対しても多様なアク セスを保障している。NICD は情報サービス専門 機関として, クライエントに対する敏速な回答を 自らのサービス評価のパラメータとしており, あ らゆる問い合わせに対して 2 週間以内の回答を業 務目標に挙げている。1992 年度の統計資料によ れば，10400 件の年間問い合わせ件数に対し，94 $\%$ は 2 週間以内に回答しており, 電話と直接来所 による問い合わせの $33 \%$ に対しては, その場で 回答が可能であった。

前述のとおり NICD には毎年膨大な問い合わせ があるが, 主任のロレイン女史によれば，これら の問い合わせには一定の質問パタンがあるという。 NICD では過去 10 年間の問い合わせ実績に基づ き，問い合わせが頻繁にある事項についてはあら かじめ回答用のリーフレットを用意している（図 5 )。このリーフレットの利用により, クライエ ントの問い合わせに対する敏速な回答が可能となっ ている。電話, 手紙, 直接来所のいずれかの手段 でアクセスしてきたクライエントの問い合わせに 対して, NICDではまず “Fact sheet”と呼ばれ るインテーク・シートにクライエントの個人情報 を記入する。Fact sheetには 100 種類のポピュ ラーな相談事項が印刷されており, スタッフはク ライエントの問い合わせがこれらのいずれかの事 項に該当するか否かを確認する。現在，NICD で は Fact sheet の事項に対応する約 100 種類のリー フレットが用意されているが，これらは全て NICD スタッフがクライエントに対する回答用に 情報収集ならびに編集したものである。これらの リーフレットは隔年で発行される NICD の出版物 リストに掲載されている。また，クライエントの 問い合わせが既存のリーフレットで対応できない 場合には, NICD スタッフが書架資料や図書館に おいて新たに調査を行い, 新規資料を作成するこ 
齋藤・他 全米蕌情報センター（NICD）における情報サービス

とになる。リーフレットの価格は 1 部 1 ドルから 10 ドル程度と低額であり, クライエントの第 1 回目の問い合わせに対しては無料，2回目からは 実費を徵収しており，郵送費等にあてられている。 なお,リーフレットの編集や既存のリーフレッ トで対応できない場合の報告資料の作成にあたっ ては, 次項で述べる情報管理システムが機能して いる。

\section{2. 情報管理システム}

NICD ではクライエントの問い合わせに対応す ベく, 地方の聴覚障害教育機関の所在から補聴器 の使用説明書に到るまで, 膨大な印刷体資料を収 集している。これらの資料を効率的に管理するた めに, NICDでは独自に作成したシソーラスに基 づき書架ファイルの管理を行っている。シソーラ スは聴覚障害に関する約 800 個のディスクリプタ から構成されており，ディスクリプタは毎年改訂 されている。また，NICD では書架資料の検索の 効率化を図るために, 既成のソフトウェア （InMagic）を用いて，パソコンレベルのコンピュー タデータベースを開発している。データベースに は NICD の書架資料に関する情報が入力されてお り, 検索は前述のシソーラスはもちろんのことフ リータームによって行うことあ可能である。なお, このデータベースは現在 NICD 内部でのみ使用可

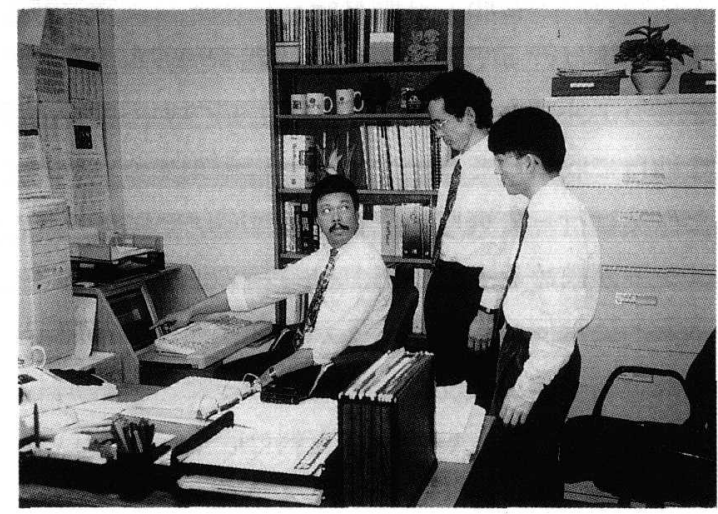

図 6、データ・ベースを説明するジョーンズ氏
能であるが, 近い将来にはローカルネットワーク により大学内の他部局からの利用も開始される予 定である。

\section{3. 他機関とのネットワーク}

NICD が全米のクライエントに対して情報サー ビスを行うにあたり，他機関との連携は不可欠で あり, NICD では聴覚障害者団体などの他機関と 積極的に情報交換を行っている。この情報交換は NICD が他機関に情報を提供するという一方通行 的なものではなく，クライエントからの問い合わ せに回答するために, NICD が地方の障害者団体 や壟学校などに情報を求めることもある。このよ うに NICD では他機関との情報ネットワークの形 成を進めており, その一環として過去 2 回にわた り全米規模で, 他機関に対するニード把握調査を 実施している。第 1 回目の調査は NICD が設立さ れるに先立ち, 1980 年にギャローデット大学が 米国保健・教育・福祉省の委託を受けて実施して おり, 現存の地方機関が実施する聴覚障害に関す る情報サービスの実態, ならびにこれらの機関の NICD に対するニードを調查したものである ${ }^{1} 。$ この調查では大部分の地方機関が NICD との積極 的な情報交流を希望しており，特に，高等教育機 関，市民サービス機関，精神衛生機関では NICD に対する協力の要望が強かったことを報告してい る。さらに, 第 2 回目の調查は 1988 年に実施さ れており, 近い将来における NICD コンピュータ・ データベースのオンライン化時代をにらみ, 改め て中央の NICD と地方機関における情報サービス の役割分担について検討をしている。この調査で は中央の NICD が担うべき役割として，1）米国 における「聴覚障害情報センター」の基本的モデ ルの開発，2）地方機関の情報サービス活動の援 助，3）地方機関のスタッフの育成，4）全米規 模で実施されるプログラムやサービスの情報提供, 5 ) 首都ワシントン DCにおけるプログラムやサー 
ビスを開発すること，という5 機能の必要性を指 摘している。一方, 地方機関が担うべき役割とし ては，1）地方における社会資源の開発，2）地 方で対応可能なプログラムやサービスに関する問 い合わせへの回答，3）参考資料収集の努力，4） 地方において実施されるプログラムやサービスに 関する情報を NICD のデータベース入力すること, を挙げている。ほかに，NICD が米国規模の情報 ネットワークを形成するにあたり, 重要な役割を 担っているのがギャローデット大学地方センター (regional center) である。現在 9 箇所ある同セ ンターは，いわば機能的には中央の NICD と地方 機関との中間に位置し, 地方の壟学校や大学といっ た諸機関と協力しながら，聴覚障害に関する情報 サービスならびに生涯教育活動を行っている5 残念ながら, 現在のところ同センターから NICD のデータベースをオンライン利用することはでき ないが，同センターでは NICD が発行する各種印 刷体目録や先述のリーフレットを用意している。

\section{IV. おわりに}

わが国における聴覚障害者に対する情報サービ スのありかたについて，著者らはこのたびの NICD の調査から，下記に挙げるいくつかの示唆 を得た。

第一に NICD における情報の公開性と中立性と いう点を挙げねばならない。現在の日本では聴覚 障害に関する専門的情報をむつのは一部の専門家 個人に限られており，NICDのように專門的情報 を中立的立場から収集し，その情報を聴覚障害者， 健聴者を問わず，だれすが簡単に入手できる機関 というあのは存在しない。わが国の現状では，専 門家の数も限られているため, クライエントが求 める専門的な情報を NICD のように短時間で入手 することは極めてむつかしい。情報の中立性とい う観点については，一例として聴覚障害児教育に
おけるコミュニケーション手段についての情報の 取り扱いが挙げられよう。聴覚障害児教育の現場 では聴覚口話法と手指法という異なるコミュニケー ション手段をめぐって長い間，専門家の間で激し い論争が続いている。NICD では中立的な立場か ら聴覚口話法と手指法の双方の資料をクライエン トに提供しており，クライエントは入手した情報 のなかから自己の価值判断に基づいて情報を取捨 選択することが可能となっている。わが国の場合 には，教育や福祉の専門家の間でインフォームド・ コンセントが浸透していない現状があり，情報源 となる専門家が自己哲学に基づいた情報のみをク ライエントに提供するといった極端な例も見受け られ, 児の教育について相談した養育者が専門家 ごとに異なるアドバイスを受け，情報に翻弄され るといった深刻な事態も起きている。今後, わが 国においてもクライエントの主体的な問題解决を 支援し，中立的な立場加ら聴覚障害に関する情報 を提供する専門情報機関の設置が強く望まれる。

第二には NICD の情報サービスシステムが挙げ られよう。NICD では情報専門機関として，クラ イエントに対する情報提供を前提とした情報の収 集ならびに管理, 開発といった作業が行われてい る。ところで, NICD とギャローデット大学図書 館は密接な関係を有しているが, クライエントに 対して両機関は独立したサービスを提供している。 すなわち, 図書館では聴覚障害に関する図書や雑 誌の収集は行っていても, 補聴器や ADA（障害 をもつアメリカ人に関する法律）についての情報 を独自に収集してリーフレットに編集するといっ た作業は行っていない。また，NICDではクライ エントが求めるあのであれば資料の形態は問わず 基本的には何でも収集するが, 図書館では補聴器 の解説書や聴導犬団体の名簿といった，図書にも 雑誌にも該当しない特種な資料は収集していない。 このように聴覚障害者に対する情報サービスを整 備するにあたっては，わが国においてす，公共図 
書館等の地域の図書館が聴覚障害者を受け入れる 体制を整備することに加えて，聴覚障害に関する 情報を専門に収集ならびに加工する専門情報機関 の設置が不可欠であると考えられる3)。

第三には先述した NICD における地方機関など との積極的な情報ネットワークの形成が指摘され ねばならない。わが国の場合, 竩学校や聴覚障害 者団体，福祉施設，病院などの間で正式な情報ネッ トワークは形成されておらず，情報の交換は専門 家同士の個人的な連絡に頼っているという現状が ある。今後, わが国においては聴覚障害者情報提 供施設が全国的に設置されることが予想されるが, これらの施設が地域における情報ネットワークの 中核となることが期待されよう。

\section{参考文献}

1) Harselm BP, Hawkins - Shepard C. Development of a National Information Center on Deafness. Final Report on National
Survey of Information Needs and Services Relating to Hearing Impairment. Washington, D.C., Gallaudet College, 1981.

2 ) Moores DF. ギャローデット大学の教育。ろう 教育科学 $1994 ; 36(3): 103-6$.

3 ）日本図書館協会障害者サービス委員会，すべての 人に図書館サービスを一障害者サービス入門，東 京: 日本図書館協会, 1994.

4) 小野康二. 熊本県聴覚障害者情報提供センターの とりくみから：映像制作を中心に，障害者の福祉 $1994 ; 154: 14-5$.

5 ) 齋藤友介, 中嶋和夫, 高山忠雄. 英国王立壟研究所 （RNID）附属図書館の情報サービス，医学図書館 $1994 ; 41(2): 220-5$.

6 ）齋藤友介, 草薙進郎. 米国ハワイ州における成人聴 覚障害者サービス，ろう教育科学 $1995 ; 37(1)$ (印刷中)

7 ) Saito Y, Kusanagi S, Anme T, Takayama T. Information Service System for tha Deaf in Japan. 4th Asia Pacific Congress on Deafness (Manila). Book of Abstracts. 1994; 120.

8 ) 全日本ろうあ連盟. 聴覚障害者福祉センター（聴 覚障害者情報提供施設）モデル・プラン資料集. 東京:全日本万うあ連盟，1993。 